\title{
New Zealand Local Government Funding Policy Reform
}

\section{Claudia Scott}

\begin{abstract}
A of July 1998, all local authorities in New Zealand are required to comply with financial reforms as promulgated in the Local Government 1 Amendment Act (No. 3) 1996. The legislation promotes 'prudent, effective and efficient financial management' and supports earlier financial and accountability reforms - such as the Companies Act 1993, the Financial Reporting Act 1993 and the Fiscal Responsibility Act 1994 (Scott, 1995).
\end{abstract}

The Act provides incentives for each local authority to improve its performance in the areas of policy and strategy. Key tasks include the preparation of long-term (10 or more years) financial strategies as well as funding, borrowing and investment policies. The financial reforms include major changes to the borrowing powers of councils and build on earlier reforms - such as the replacement of traditional cash-based with accrual-based accounting systems.

This article considers the background to these reforms and reflects on their likely impact on the sector. Particular attention is given to funding policies, with attention to a few theoretical and practical issues surrounding their design and implementation. Funding policy reforms are of special interest because the changes represent significant extensions to the frameworks developed at the central government level.

The funding template involves the application of the public finance concepts of pure private and pure public goods as part of a three step process for determining the benefits from significant activities. Funding design seeks to establish a good matching between the distribution of benefits from activities undertaken by local authorities and the allocation of the costs of financing such services. Designing a funding system requires authorities to make decisions on the nature and mix of funding tools to be used for each activity. The funding template may be modified subsequently, once account is taken of other considerations, including administrative efficiency.

The new procedures require authorities to take into account a wide range of factors when designing funding policies. These include the reasons why

Claudia Scott is Professor of Public Policy in the School of Business and Public Management at The Victoria University of Wellington and is engaged in research on local government funding issues. 
particular activities are to be undertaken and the nature and kind of benefits which result from such services. Other factors for consideration include the nature of fairness and intergenerational equity, transaction costs and the existence of economies of scale and scope.

At the developmental stages of the legislation, there were substantial segments of the business and government communities which predicted that major changes to policy and practice would result. Some business and ratepayer groups viewed the legislation as a vehicle for constraining local authority expenditures. Local authorities were concerned that the legislation would remove local policy discretion and impose limitations on the range of funding tools and approaches which could be used. Some councils feared that they would be required to impose user charges for services which traditionally were funded from rates.

Modifications made to the legislation prior to its enactment had the effect of shifting emphasis from a more prescriptive approach to one which promoted clarity of policy intent and transparency of policy processes. Nine local authorities decided to comply with the legislation a year earlier than was required, and this provides some experiences to draw upon when measuring likely impacts.

\section{Context for the Reform Proposals}

Financial management and public sector reforms at the central government level provided the inspiration for these changes. These reforms have promoted greater clarity and institutional separation of policy advisory, regulatory, and service delivery roles. Local authority commercial and trading activity has been reorganised into separate business units or Local Authority Trading Enterprises (LATEs) and policies have been introduced which enhance competition and contestability in local authority service provision.

An understanding of the scope and role of local governments and previous reform efforts provides an important context for the latest legislative changes. New Zealand local governments are statutory creatures of central government, from whom all taxing powers are derived. Section $37 \mathrm{~K}$ of the Local Government Act 1974 (as amended in 1989) lists a set of purposes, and while these provide considerable discretion, local governments do not possess a power of general competence.

City and district councils are responsible for the following functions: community well-being; environmental health and safety; infrastructure including roading and transport, sewerage, water/stormwater; recreation and culture; resource management, including land use planning and development control. Regional councils are responsible for the following functions: resource management; biosecurity; catchment control; harbour administration; regional civil defence; and regional land transport. 
Local authorities provide 39,300 jobs, have annual operating expenditures of $\$ 3.3$ billion, have $\$ 33$ billion in ratepayer equity and $\$ 35$ billion of term assets. The ratio of local authority expenditure to gross domestic product is 3.5 per cent (Local Government New Zealand, 1998:3).

The core business of local government, traditionally, has been the delivery of services, regulation and the ownership and management of infrastructure. Authorities in the larger urban areas have assumed a number of wider social and economic development roles; however, local governments have no direct responsibility for education, health or social services.

In 1989-90 the Labour Government introduced a number of structural reforms to local government. The Local Government Amendment Act (No. 2) 1989 reduced 625 local authorities and developed a more consistent and uniform structure of regions, districts and communities. There are now 12 regional councils and 74 local authorities, which include 49 Territorial Local Authorities (TLAs) and four unitary authorities which function as both the district and regional council levels.

A total of 156 community boards also exist, which are not a sub-district level of government but to whom certain functions and powers are assigned by the TLAs. There are over 1,100 elected members of local government. While the local government reform agenda gives consideration to matters concerning function, structure and funding, by far the greatest attention has been given to structural reform.

Revenue sources for local government rely heavily on the rating system which may operate on the basis of land (formerly unimproved), annual or capital value. The last is in common use in urban areas and land value is often used in rural areas. There is provision for separate rates to finance particular services and also special rates to finance loans for capital works. Other funding tools include uniform charges (a standard charge on all ratepayers for specific services) and uniform annual general charges (a device which ensures that all ratepayers pay some minimum amount).

In most countries, the value of property is the key determinant which influences the rates paid by different properties. Differential rating alters this, however, because it provides councils with the power to vary the general rate on different types and groups of properties. In the New Zealand context, differences are linked to particular characteristics of the property including land use, geographical area and in some cases, property value itself. When differential rating is applied, a separation is made between property value and rating liability, thus introducing political judgements and discretion into the taxation system.

The financial reforms evolved during a period in which some state-owned enterprises and businesses were mounting successful legal challenges to the funding systems of local authorities. Litigants opposed practices whereby councils were utilising their differential rating powers to cost-shift from 
residential to commercial ratepayers, imposing burdens which were disproportionate to the level of benefits received.

The success of a few litigants led to further actual (and threatened) challenges. Some of these threats resulted in out-of-court settlements which did not preserve horizontal equity among ratepayers. Challenges in the courts resulted in decisions which declared the existing local authority rating system to be deficient but then left the two parties to negotiate a more appropriate and acceptable outcome. The legal challenges made to local authority funding systems imposed substantial costs on both the litigants and on local authorities.

\section{Key Features of the Reforms}

The following figure portrays the way in which the funding requirements of the Local Government Amendment Act (No. 3) 1996 can be linked to the wide strategic planning processes and responsibilities of local councils under the Resource Management Act.

\section{Strategic Planning Processes in Local Government}

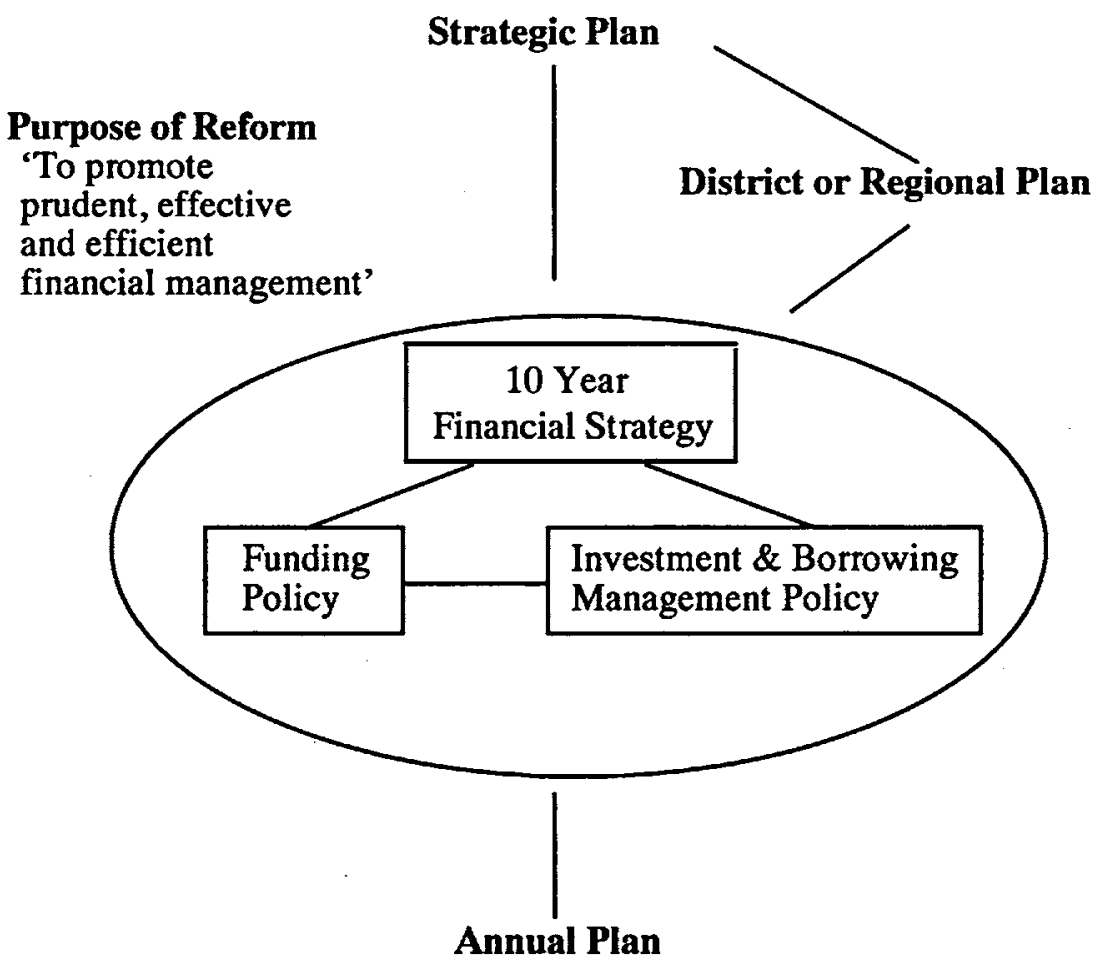


Local authorities are not required to produce a strategic plan. At a minimum, however, indications of strategic intent are necessary to inform regional, district and annual plans and to link to a council's financial strategy, funding policy and investment and borrowing management policy. The Act includes specific requirements for public consultation about the financial management policy proposals.

The financial strategy goes beyond simple forecasts or projections of cash flow and must include a combination of a strategic vision and goals together with concrete financial data on costs (at least for the first three years). The funding reforms remove several borrowing restrictions, and allow authorities to borrow on the same basis as commercial enterprises, with the exception of borrowing in foreign currency. Unlike central government, local authorities have been fundamentally conservative in their borrowing behaviour. In contrast, central government has only achieved a positive net worth as of 1996.

An innovative feature of the changes concerns the way in which authorities are now required to design a funding policy by giving attention to the linkages between the distribution of the costs of local government services and the individuals and organisations who benefit from the services. Particular principles must be followed in selecting funding tools and associated funding arrangements, including user charges or user-related charges and differential rating.

Councils have shown a preference for maintaining uniform charges and uniform annual general charges over the adoption of user charges which vary with service use. Uniform charges have allowed councils to extract a minimum contribution from properties and to even out the contribution across properties and households - thereby reducing the overall progressivity of the rating system.

The Act requires authorities to develop its funding policy by means of a three step process: the first applies specific principles to the allocation of costs, the second modifies these arising from equity or policy concerns, and the third selects the funding tools and designs the overall funding system. Step one requires councils to determine the allocation of costs on the basis of the four economic principles, as outlined in section $122 \mathrm{~F}$. The principles can be loosely characterised as: (a) intergenerational equity - benefits accruing over time should be funded over time; (b) community-based funding - public benefits to the community should be funded from the community generally; (c) user pays - persons receiving direct benefits should fund those benefits; and, (d) exacerbator or polluter pays - persons directly causing costs should pay for those costs.

Step two asks councils to modify the theoretical allocation based on four considerations in section $122 \mathrm{G}$ including: (a) obligations to act in the interests of residents and ratepayers; (b) fairness and equity in the allocation of costs; (c) any lawful council policy which may be appropriately promoted by the 
allocation of expenditure; and, (d) avoiding adjustment difficulties arising from sudden and significant changes in cost allocation, balanced against achieving the identified cost allocation at the earliest reasonable date. .

Step three asks councils to consider the extent to which it is practicable and efficient to fund a particular expenditure need in a way that achieves or approximately achieves the allocation of costs determined in step two, having regard to: (a) the extent to which any mechanism(s) can achieve any allocation of costs; (b) efficiency in terms of the cost of different mechanisms; (c) the efficiency and effectiveness of making use of separate funding mechanisms; and, (d) the transparency of the available funding mechanisms in funding the particular expenditure need.

\section{From Draft Stages to Final Enactment}

The Local Government Act (No. 3) 1996 requires a detailed specification of the functions which are to be carried out, the policy rationale for undertaking the function, the nature and distribution of benefits arising from the function and the way in which the authority proposes to fund the activity. The rather prescriptive nature of the draft legislation and the prominence given to economic principles led some to speculate that the legislation had the potential to limit the scope of activities and reduce the tax burdens on business properties.

The New Zealand Business Roundtable (NZBR), an organisation of chief executives of major New Zealand business firms, supported the legislation on the grounds that it would make authorities more accountable and transparent in their funding and expenditures decisions. In a submission commenting on the draft legislation, the NZBR argued that authorities should act primarily in the interests of the ratepayers of the district, be required to provide specific reasons as to why activities were being undertaken, and provide justification for cases in which the council rejected options involving a greater degree of user pays and/or private provision (NZBR, 1995).

The final legislation requires authorities to act in the interests of the district of the local authority and its inhabitants and ratepayers. Local governments became concerned about the legislation's potential to constrain the role of local government and brought pressure on the government to soften particular provisions, including the influence of economic principles on funding approaches. Relative to the Bill, the final Act gave councils more discretion regarding the implementation of the three stage process, particularly with regard to the extent and detail of information to be considered, and the evaluation of the costs and benefits of alternative funding options.

The legislation allows authorities to modify their step one economic approach to the analysis of benefits with considerations at step two of a political nature. These include judgements about fairness and equity, and the degree to which the principles are relevant to particular functions. Such changes have 
acknowledged the difficulties and transitional problems which authorities may occur when major changes are made to the distribution of rating burdens across groups.

While councils must engage with some difficult economic principles, legal issues are also important because of the desire of authorities to avoid legal challenges. A common way for legal advisers to portray the new three-step funding process is to label step one as 'economic efficiency', step two as 'political equity' and step three as 'practical legality'. A High Court decision underscored the view that rates were a tax and not a user charge, although earlier judgements placed emphasis on the idea that rates were a payment for services received.

The Act makes it clear that it is the process which is being mandated rather than any requirements in terms of the appropriate scope and role of local government or templates for the funding of particular functions. Another softening of the legislation limits the potential to review the funding process itself, and requires that challenges be made by way of written submission in the course of the special consultative procedure.

The new legislation was enacted shortly after the Court of Appeal decision in Wellington City Council $v$ Woolworths. This ruling affirmed the principle that council funding decisions are essentially a matter for the council. The decision argued that if a council followed proper procedures, the courts would not interfere, except in clear and extreme cases. This view was given further support by a second appeal decision (Waitakere City Council v Lovelock).

These court decisions served to allay fears that the legislation would have led to prescriptions regarding the scope and nature of local authorities and the manner in which particular activities are funded. It is now unlikely that the Courts will intervene in the specifics of funding proposals except where the decisions are perverse or outrageous.

\section{Some Theoretical Considerations}

Public funding and delivery of local government services are often justified on the grounds that benefits extend beyond direct users of the service to others in the community. Economists describe these benefits as externalities (or alternatively, third-party community benefits) and suggest that externalities result in 'market failure' and a possible rationale for government intervention. If externalities exist there are two consequences. First, funding and provision of the service by the market leads to under-supply and second, it is no longer appropriate to require that the direct users of service meet the full cost of the service.

Policy discussions surrounding the draft Local Government Amendment Bill gave undue attention to the concept of pure private and pure public goods as key determinants in assigning benefits and costs from services. Pure private goods 
exhibit the characteristics of being rival and excludable, whereas pure public goods are non-rival and non-excludable.

While many councils have or are developing funding policies which draw on economic principles, some are more successful than others in applying economic concepts in an appropriate manner. Some authorities have put too much emphasis on the public and private goods concepts. In practical terms, few services confer exclusively private benefits to readily identifiable individuals who can be charged, or alternatively provide only communily-wide benefits to all. In the real world, many services are mixed and reflect both private benefits to individuals and public benefits to the wider community.

The distribution of benefits from services and the selection of particular funding tools can be expected to vary across different local authorities. For example, one authority may deliver a service because members of the community will receive benefits from extending opportunities to others. In a second authority, a similar service may yield primarily private benefits to direct users. Thus, the distribution of public and private benefits will differ from one authority to another, as will the appropriate level and mix of funding tools.

Another source of economic confusion arises from the expectation held by some, that it is fair to require businesses to fund services in proportion to the benefits they receive from services in their role as businesses. The view fails to distinguish legal from economic incidence and incorrectly assumes that the person who pays rates is the only individual who meets the burden of the tax.

In fact, the burden of rates paid by businesses may be shifted in whole or in part to consumers. Moreover, since rates are an indirect tax, rating authorities are unable to design rating burdens which link the benefits received from services to the circumstances of specific individual or corporate ratepayers.

\section{Initial Impacts of the Legislation}

A survey of councils who were early compliers with the legislation reports that the application of the three step process led to changes to the mix of funding approaches used in each of the nine councils surveyed. Councils split evenly between those which reported moderate change in funding approaches and those reporting very little change. While all councils reported some change, no council reported very significant change (Centre for Research in Public Management, 1997).

Analysis of the application of the funding principles across the nine early compliers shows a relatively consistent approach to measuring the public and private benefits from services. Table 1 shows the estimates provided across the nine authorities in terms of the share of public and private benefits attributed to a range of different local authority services. The nine authorities ranged in size from Opotiki District with a population of 9,375 to Wellington Regional Council with a population of 412,500 . 


\section{Table 1: Modified Costs Allocations - Summary of Step 2 for a Sample of Council Functions}

Function

Libraries
Civil Defence
Rental Housing for the Elderly
Solid Waster Management
Sportsfields
Parks/Beaches
Wastewater
Parking
Transport/Roading
Democratic Representation

Public/Private Benefits (\%) (Level or range)

$80 / 20$ to $95 / 5$
$100 / 0$
$0 / 100$
$10 / 90$ to $30 / 70$
$75 / 25$ to $93 / 7$
$85 / 15$ to $97 / 3$
$5 / 95$ to $85 / 15$
$0 / 100$ to $25 / 75$
$23 / 77$ to $100 / 0$
$100 / 0$

$100 / 0$

$0 / 100$

$75 / 25$ to $93 / 7$

$85 / 15$ to $97 / 3$

$0 / 100$ to $25 / 75$

$23 / 77$ to $100 / 0$

$100 / 0$

Source: Centre for Research in Public Management (1997:7).

There is some evidence that councils have been reluctant to introduce major shifts to their former approaches to funding. In a few cases, it appears that authorities have stopped short of giving consideration to the full range of policy options - including options of existing services or relinquishing their ownership roles.

Those who would like to see a leaner and more focused local government have expressed some concern that in some urban areas, there seems to be a continuation of past practices. These include owning shares in commercial enterprises such as energy companies, providing tourism and business development services and owning and operating off-street parking facilities. In several main urban centres, the differential rating of businesses continues, and expenditure levels are rising.

Central government has initiated a major review of arrangements surrounding the ownership, funding and management of roading. Existing funding arrangements are a mixture of part tax, part road user charges and part rating, but various alternatives are under consideration. Roading expenditure comprises approximately 20 per cent of operating costs in major urban authorities and can represent up to 60 per cent of the expenditure of rural authorities. Thus, roading reforms are likely to have very major impacts on the size and scope of the local government sector (Local Government New Zealand, 1998:14). 
Reforms are also occurring in the area of water and waste water and there are pressures on authorities arising from the need for substantial levels of new investment and an upgrading of existing assets. Several servicing options are being explored for the future including contracting out, franchising, interregional entities, formal joint ventures and privatisation.

Although local authorities do not have direct responsibilities in the area of social policy, many are now supporting the work of central government and non-profit agencies. In the area of 'strengthening families', local authorities are assisting in the implementation of strategies which will draw resources from across the health, education, social services and justice portfolios. While formerly local authorities were best known in their service delivery role, there is growing acceptance that it is the governance role of local authorities which is unique and should be regarded as its core business (Reid, 1994).

A useful contribution to the debates on the future role of local government is the recent publication of three alternative scenarios for local government in 2010 (Minister of Local Government, LGNZ and SOLGM, 1998). The three scenarios are: 'Muddling Along', 'Lean and Competitive', and 'Governance for Citizens'. The scenarios move along a continuum in which there is a shift in the role of local government away from service delivery and toward the provision of governance and leadership at the local level, the brokering of 'local solutions to local problems' and working with central government and communities to resolve intractable problems in areas like health, education, employment and welfare.

Local authorities are becoming more closely involved with the policy agenda of central government and some have assumed an advocacy role for the expression of local views. It is unlikely, however, that local governments will inherit major new roles as the agent of central government. This is partly because local authorities have a reputation within central government as being too small and too conservative to foster economic and social development in a community setting.

\section{Conclusions}

Public management reforms at the central government level are an important source of inspiration for the local government reform agenda. Recent reforms have served to clarify governance and management roles and led to a reconsideration of the appropriate role of local government in the areas of policy, service delivery, regulation and ownership.

The funding policy reforms are still in the early stages of implementation. Available evidence suggests that policy impacts of the legislation are smaller than was anticipated and the compliance costs are significant and warrant measurement and monitoring. Changes to service delivery in areas like 
roading, water and waste are serving to reinforce and strengthen the principles and provisions of the new Act.

Councils can expect to face growing pressures from their residents and ratepayers to provide more robust and coherent policies to explain why they undertake particular functions and activities and their approaches to funding such services. The legislation on its own is unlikely significantly to constrain the scope of local government activity but rather to make policy roles more transparent. It is likely that the diversity of roles and responses across local governments will persist, an outcome which some suggest provides the very rationale for the existence of local governments.

In December 1998 a discussion paper was released by the government as part of a process of reviewing local authority funding powers and introducing new legislation to take effect in the 2000-01 financial year (Department of Internal Affairs, 1998). The paper in some respects adopts a zero-based approach to the future funding powers of local authorities.

A joint Local Government New Zealand (LGNZ) and Society of Local Government Managers (SOLGM) Working Party suggests that the government's discussion paper reflects the view that local governments have not met central government's expectations regarding efficiency gains (LGNZ and SOLGM, 1999). There is the view at central government level that changes to funding tools and associated processes are required if full benefit is to be gained from the new financial management provisions.

The Local Government Act (No. 3) 1996 has brought improvements in accountability, though at the price of substantial compliance and administrative costs. While the Government's discussion paper outlines a number of different alternative proposals, several options are raised which would reduce the wide range of funding tools which are currently available. Examples include the proposal to move to a single approach for general rates (such as compulsory land or capital value), prohibition on differential general rates (other than by geographical location) and abolition of the uniform annual general charge. Proposals are also contained for new processes which may be applied with regard to existing and new funding powers.

For many years, local authority reform placed its focus on structure. Thus, the current attention on issues concerning function and funding - and the linkages between them - is most welcome. Yet, so long as uncertainties remain regarding the appropriate role and function of local authorities, this will limit the capacity of policy makers to make judgements concerning particular funding tools and associated funding arrangements. 


\section{Claudia Scott}

\section{References}

Centre for Research in Public Management (1997), Local Government Financial Reforms Volume 2: Funding Policy and Consultation Process Review, 27 November.

Department of Internal Affairs (1998), A Future Direction for Local Government Funding Powers: A Consultation Document, December.

Local Government New Zealand (1998) 'Briefing Paper to the Minister of Local Government', September.

Local Government New Zealand and Society of Local Government Managers (1999), Heading in the Right Direction, Wellington, January.

Minister of Local Government, LGNZ and SOLGM (1998), Scenarios for Local Government to 2010, Wellington.

New Zealand Business Roundtable (1995), 'Submission to the Internal Affairs and Local Government Committee on the Local Government Law Reform Bill', March.

Reid, M. (1994), 'Local Government - Service Delivery or Governance?', Public Sector $17(2): 2-5$.

Scott, G. (1995), 'Fiscal Responsibility Act', Agenda 2(1):3-16.

The author acknowledges the assistance of the Editor and two anonymous referees. 